\title{
The Imagined Disastrous: West German Civil Defence Between War Preparation and Emergency Management 1950-1990
}

\author{
Jochen Molitor
}

There is a ubiquitous quality to the term 'disaster'. ${ }^{1}$ While it is certainly used to refer to worst-case scenarios or-adhering to a more technical definition-to events which exceed locally available resources (Münkler 2013: 135), it is probably more often utilised to describe mere inconveniences, especially in everyday life. The inherent character of the expression seems to encourage its use in vastly different circumstances ranging from the outrageous to the casual, from the horrific to the banal (Münkler 2013: 95). Without denouncing the pressing factuality of many catastrophic events, as some scholars tend to do, ${ }^{2}$ an event does not necessarily have to be disastrous in and of itself to be labelled as such, and a disaster may just as much be considered a product of communication than of the forces of nature or the dangers of technology (Imhof 2004: 145). It is this relativity and context-dependency which has encouraged

J. Molitor ( $₫)$

University of Cologne, Cologne, Germany

(C) The Author(s) 2022

M. Cronqvist et al. (eds.), Cold War Civil Defence in Western Europe, https://doi.org/10.1007/978-3-030-84281-9_3 
scholars to be mindful of the term and observe the specific circumstances of its use. Beyond influencing two of the more recent general studies on contemporary West German ${ }^{3}$ history, which has been characterised as a 'search for security' (Conze 2009) in a 'republic of fear' (Biess 2019), questioning who prepared when and for what 'disasters' seems highly instrumental for studying the civil defence endeavours of the Federal Republic of Germany. Accordingly, this chapter will focus on retracing the nature of the dystopian sociotechnical imaginaries (see the introduction to this volume) put forth by West German civil defence institutions, how they changed over time and what measures were taken to counter them. Using the term 'imagined disastrous' to stress both the act of imagining and that of labelling, it shall be argued that the relativity of the employed terminology allowed civil defence officials to model and adapt their proposed sociotechnical imaginary to befit the amount of preparation actually attainable by them.

\section{Disaster as Rhetoric, War as Reality: Early West German Civil Defence i950-I968}

The Second World War and the experience of national defeat are frequently referred to as 'the disaster' (die Katastrophe) in early sources of the Federal Republic. Since labelling something as such is usually connected to the assumption that what has happened was the unintentional result of external forces (Münkler 2013: 97), this seems to reflect the widespread tendency of the new state to look for excuses rather than face accountability for the war (Moeller 2001: 94). During the 1950s, West German civil defence officials regularly employed similar terminology to obscure that the object of their preparations was, indeed, another military conflict, in which the divided Germany constituted the most prominent frontline between the opposing military alliances of the NATO and the Warsaw Pact. However, the underlying imagined disastrous was not so much based on the theoretical premises of nuclear warfare, but rather on first-hand experiences of the allied bombings of the recent past (Steneck 2005: 126-129). ${ }^{4}$ Thus, early civil defence concepts had more in common with National Socialist air raid precautions than any kind of modern emergency management. ${ }^{5}$ In addition, much of the same personnel was present (Diebel 2017: 36-37), and after talks started in 1948, official preparations intensified from 1950 onwards. 
The foundation of a so-called Protective Commission (Schutzkommission) in 1951 aimed at funding scientific research on, for example, radiation sickness and the protective effect of different shelter types, while two organisations-the Federal Air Raid Protection Association (Bundesluftschutzverband, BLSV) and the Federal Agency for Technical Relief (Bundesanstalt Technisches Hilfswerk, THW) ${ }^{6}$ aimed at educating volunteers in self-preservation measures and rescue operations. In late 1958, the basic organisation of a new West German civil defence system was finalised with the establishment of the Federal Office of Civil Defence (Bundesamt für zivilen Bevölkerungsschutz, BzB), which was to coordinate the various efforts. ${ }^{7}$

Although this organisational setup might in retrospect seem quite structured, its factual effectiveness beyond mere bureaucracy may well be questioned. A good example is the constant denial of policymakers to adhere to the central demand of basically all West German civil defence officials during the 1950s and early 1960s: for the widespread construction of shelters to protect the population at least from conventional bomb blasts and nuclear fallout. The first law including a prerequisite that all newly built houses were to have some sort of shelter facility was passed as early as October 1957. However, its main paragraph was immediately postponed and later dismissed due to its financial implications. Additional attempts to legally enforce or at least effectively support privately funded shelter construction suffered a similar fate; politicians of all parties simply did not want to commit to it (Steneck 2008: 82). Germany was thought to be a traumatised country with a populace bent on forgetting about the possibility of war rather than being constantly reminded of it (Molitor 2011: 44-50). Thus, even during the high point of construction efforts and across all crisis situations of the Cold War, West Germany could only provide public or private shelter spaces for approximately three per cent of its inhabitants (e.g. Geier 2003: 56). Civil defence officials glanced enviously at their neighbours in Switzerland, where basically everyone was provided for (cf. Berger Ziauddin 2017) and continued to insist: 'Without shelters, there can be no civil defence, and without them serving as the backbone, even the most effective organisational preparation will remain bogged in the merely hypothetical' (Sautier 1961: 47).

It was in this context that West German officials of the time often spoke of 'disasters' and shied away from the unpopular term 'war' as much as they could. However, in contrast to first aid or firefighting training, shelter construction eluded any serious kind of secondary use in times of peace 
and continuously brought home what the purpose of civil defence really was. Ultimately, the notion of any need for shelter construction revealed that the discourse around 'disasters' was merely a façade erected by officials who simply did not dare to tell the truth about their own profession. The separation of jurisdictions in the Federal Republic also highlighted this incongruity. While civil defence was, and still is, part of the national defence strategy, falling under the remit of the federal ministry of home affairs, disaster relief is considered a local endeavour, with the individual states governing their own varying regulations and institutions. Due to this legal separation, any talk of disasters by federal institutions such as the $\mathrm{BzB}$ was bound to come across as disingenuous, since they had no jurisdiction in these matters to begin with. Thus, the imagined disastrous of West German civil defence officials during the 1950s and early 1960s was clearly focused on a war against the forces of the Soviet Union and the Warsaw Pact. Initially it was imagined that this war would be fought with conventional weapons, but later it was envisaged as an allout nuclear exchange for which West Germany, as the front state, would have to engage in total defence-reversing the National Socialist dictum of total war.

During the early 1960s, this line of thinking began to change. The widely debated paradigm shift in NATO's strategic doctrine from 'massive retaliation' to 'flexible response' (cf. Schmidt 1961 as a contemporary treatise from a German point of view), which promised 'appropriate' military reactions to perceived threats rather than total annihilation, made smaller conflicts more likely and meant that civil defence measures could actually prove somewhat effective (see also chapter by Farbøl this volume). Additionally, the idea that at least some such measures might also be helpful during natural or technical disasters became gradually more widespread. An early example was the North Sea flood of 1962, in which West German civil defence organisations-especially the THW, but also the BLSV-provided substantial assistance, despite not being officially responsible for local disaster relief (cf. Molitor 2014). While these organisations had traditionally spoken of disasters as a metaphor for a possible war, many contemporary sources show how much the actual disaster was now portrayed as warlike: the flood was described as an aggressor which had to be fought by daring heroes in a selfless struggle. This kind of work, for example within the uniform-wearing THW, might have offered many veterans of the former Wehrmacht-the army of National Socialist Germany-the opportunity to bask in a form of well-known martial 
rhetoric, now targeted at a non-human enemy and utilised for beneficial purposes, thus harking back to a cherished set of ideals purged of its former ideological content (Molitor 2014: 204-210).

Among other developments, events such as the flood of 1962 paved the way for the dual-use strategy put forth by civil defence officials from the mid-1960s onwards, resulting in probably the most significant West German civil defence law: the Act on the Expansion of Disaster Relief (Gesetz zur Erweiterung des Katastrophenschutzes, KatSG68), passed in 1968. Misleadingly referring to civil defence as 'expanded disaster relief', the law was a political reaction to the dilemma that even a substandard civil defence system required cost-intensive investments, which-according to West German jurisdictions-could not be legally used except in the case of war, which everybody was desperately seeking to avoid. In contrast to that notion, the KatSG-68 demanded that federal authorities support the individual states' disaster relief efforts and, for example, grant them access to the THW as long as the states guaranteed the use of their equipment and institutions for civil defence efforts should the need arise. While this did not dissolve the traditionally split responsibility between federal civil defence and local disaster relief, it entangled them systematically in making one reliant on the other. The premise that preparedness in general had to be improved furthered the prioritisation of measures which could be useful in a variety of scenarios-alert systems, first aid education and so on-over prohibitively expensive and unwieldy genuine civil defence preparations such as shelter construction (cf. Diebel 2017: 76-79).

This trend towards what should later be called the 'all-hazards' approach can clearly be illustrated by comparing two of the key West German civil defence documents: the educational pamphlets Jeder bat eine Chance (Everybody has a Chance) and Zivilschutzfibel (Guide to civil defence). Both were published by the $\mathrm{BzB}$ and distributed for free to all households in 1962 and 1964, respectively. At the time, Jeder hat eine Chance was massively criticised for downplaying the nuclear threat, because it maintained that, depending on the distance of a nuclear detonation, even simple measures such as taking cover, protecting naked skin and looking away might prevent harm. The Zivilschutzfibel, however, fared somewhat better in the eyes of the public (Steneck 2005: 284-285; Biess 2009: 87-88). Released merely two years later, it contained all the relevant information of Jeder hat eine Chance, but while the original had clearly focused on the threat of war, the revised version (at fifty pages 
more than twice the size of its predecessor) began with the following statement, signed by the minster for home affairs at the time, Hermann Höcherl:

Every day, we read or hear of unfortunate events. They threaten us at home or on the street. We're not even safe on our holidays. And, time and time again, humanity is threatened by natural disasters. [...] Even war, the biggest disaster of them all, is still a threat to many people of this world. (BzB 1964: 1)

War, as delineated in the Zivilschutzfibel, was not only labelled a disaster, but embedded within a larger framework of a multitude of possible dangers. Arguably, this played down the potential horror of an all-out nuclear conflict a lot more than Jeder hat eine Chance. Yet it also displayed a mindset which envisioned the disastrous as ranging from the trivial to the apocalyptic, with all possible dangers being somehow connected to each other, differing more in scope than fundamentally. Right in the middle of the pamphlet, a page headlined as 'An interim remark (It has nothing, absolutely nothing to do with war)' expressed this even more clearly:

There will always be natural disasters. Floods - dyke breaches earthquakes - massive fires. Don't you think that it would be hugely beneficial to know how to protect your life and your belongings? Think of the North Sea flood disaster for instance! Think of Hamburg! And what if a fire started in your own home? Maybe you could put your knowledge to good use for that! And if someone gets hurt at home or in a car accident, there'd be someone there to offer first aid - that would certainly be welcome! Even if you disregard all other arguments, these points should convince you to continue reading. (BzB 1964: 23, emphasis in original)

Again, the Zivilschutzfibel did not exclude the threat of war-it did in fact contain images of weaponry, of people taking cover and so onbut it also displayed a staggering array of possible alternatives, ranging from natural disasters to mere household fires, for which the same kind of preparation was declared useful. While its authors clearly tried to utilise disaster preparation as a less controversial means to get their point across, it must thus still be regarded as an early document publicly pushing the idea that civil defence should be generally useful. 
As darkly comical as the brochure may seem from today's perspective, with the authors' insecurity about their potential readers' disposition unambiguously showing through, the Zivilschutzfibel did have a point, and the car crash photograph illustrating its 'Interim remark' was not only chosen to downplay nuclear annihilation. From the 1960s until the 1980s, more than 16,000 people died in West German traffic every year, reaching a tragic peak with over 21,000 casualties in 1970 (Kessel 2008: $52-53$ ). If one compares these figures to the approximately 3,200 yearly traffic casualties during the 2010 s, applying to a significantly more densely populated, reunified Germany, it seems obvious that not only civil defence was deficient during the 1950s and 1960s. General emergency management, too, failed to find answers to the 'modern' threats of the time, and with most people not wearing seatbelts, no first aid courses during drivers' training and no organised emergency medical system whatsoever, even smaller car accidents could easily end up being fatal. Keeping these observations in mind, the sometimes naïve-sounding arguments put forth by the Zivilschutzfibel should not be too easily dismissed. After all, it foreshadowed a significant change in both the civil defence authorities' sociotechnical imaginary and what kinds of activities would remain popular in West Germany from the late 1960s onwards: those which not only claimed to prepare for disasters, but actually did so in some way.

\section{From the Sensationalist to the Pragmatic: Later West German Civil Defence}

It has been stated that the move away from more dedicated measures to focusing on volunteer work and multipurpose skills rather than on building shelters effectively ended West German civil defence. Conversely, more recent studies suggest that it was this very move from the sensationalist to the pragmatic which saved it (Diebel 2017: 115-116). Because historians are, by and large, prone to telling good stories and have often shown considerable sympathy for contemporary peace movements which dismissed all kinds of civil defence as government propaganda at best and war mongering at worst (e.g. Garrison 2006; Klinke 2018), many accounts have focused on the more sensational aspects, glancing over its more pragmatic variants and all but overlooking its manifold connections to disaster relief. This has narrowed the viewpoint of many studies to the timeframe discussed thus far: the early Cold War period of the 1950s and 1960s. In the case of West Germany, however, it may be argued 
that its civil defence measures became (somewhat) successful after the big crisis situations of the early Cold War, with officials widely adopting the all-hazards approach from the late 1960s onwards.

In order to trace the later developments of civil defence in the Federal Republic, it is imperative to look beyond the state and its agencies. As already hinted at, civil defence in West Germany relied heavily on various relief organisations (Hilfsorganisationen). ${ }^{8}$ Unlike the construction of shelters, the THW, for instance, was not abandoned in the 1960s, but thrived and flourished (Diebel 2017: 141-149). Today, it serves as one of Germany's foremost general relief organisations, providing refugee accommodation as well as giving aid during global pandemics. 9 The German Red Cross (DRK), too, was hardly ever criticised by even the most adamant peace activists, yet continuously supported civil defence and was quite successful in influencing its actual course during the 1980s (cf. Diebel 2017: 313-315). Just glancing at these two organisationsboasting current volunteer counts of c. 80,000 (THW) and 443,300 (DRK), respectively ${ }^{10}$ - should clarify that there was (and is) a culture of preparedness that extends beyond lofty shelter construction plans put forth by a select number of officials but repeatedly cancelled before public discussion could even start.

This chapter now turns briefly to the development of West German disaster medicine (Katastrophenmedizin), not only to examine whether or not the imagined disastrous of physicians mirrored the general developments of West German civil defence, but also to further elaborate on the thesis that there was a move from a failed, expansive total defence approach to a partially implemented, more subdued one.

\section{The Emergence of All-Hazards Disaster Medicine in West Germany i956-I989}

Physicians are interesting historical agents in civil defence research for several reasons. First of all, in the case of either a disaster or war, they are immediately involved at the frontline of the event and cannot enjoy the relative comfort of office professions. Most physicians do not work for the state but in hospitals or are self-employed, and they are generally wellrespected, well-paid and used to a high degree of professional autonomy. However, since their work requires specialised training for which there is no easy substitute, all of them are required to help in times of crisis, especially those usually more occupied with treating the common cold 
than dealing with mass casualty situations. Depending on the perspective, physicians are thus both influential actors in a field that involves multiple professions combating for areas of exclusive jurisdiction (cf. Abbot 1988: 90) and a scarce and valuable resource for politicians or civil defence officials preparing for the worst. ${ }^{11}$

It is hardly surprising that the first physicians trying to establish some sort of medical civil defence in West Germany belonged to the military. In contrast to some of the civilian officials at the time, the imagined disastrous of most medical officers quickly focused on nuclear war. ${ }^{12}$ Some certainly downplayed the potential destructiveness of this scenario and maintained that - if the planning was sound and the individual physicians masters of their craft-adequate preparations could be made (cf. Bayer 1962). However, the medical system (Sanitätsdienst) of the new West German army, the Bundeswehr, was deemed to be unfit to tackle such a task alone. Especially in the late 1950s and early 1960s, proposals were occasionally made to combine both the civilian and military spheres into an 'omnipotent' medical service, ready to face the most severe crisis situations and reflecting the sociotechnical imaginary of a shelter-based system of total defence. Still, even during the 1950s these proposals remained in the minority, since most military physicians deemed their powers to counteract the damage of the new weapons to be frightfully slim.

The 1962 large-scale NATO war exercise Fallex (fall exercise), renowned in German national history as the origin of the infamous Spiegel affair, ${ }^{13}$ may serve as an example. During the exercise, military physicians professed that under the imagined circumstances of an all-out nuclear bombardment, they could maintain their service for a mere couple of days, if at all. Navy physician Karl-Wilhelm Wedel noted in his exercise diary that Fallex imagined 89 nuclear strikes on West Germany on day one, while official sources of the Ministry of the Interior mentioned 300 nuclear strikes within a six-day period. ${ }^{14}$ Wedel warned that the general military's assessments of the casualties were far too low, stressed the large number of quick losses among the available medical personal, and pointed to an overall spread of panic and epidemics which would soon render any idea of organised medical help as completely unrealistic. ${ }^{15}$ To allow for a wider field of possible decision-making, later NATO exercises, such as Wintex in 1975, usually referred to more restrained scenarios with only a limited use of nuclear weaponry. However, medical officers still held the opinion that they could only function with any degree of effectiveness as long as weapons of mass destructions were not used, and the 
criticism was made that even a single day of chemical warfare would render their services so 'heavily afflicted' that they would be unfit to offer further assistance. ${ }^{16}$ While many military physicians presented themselves as 'uncomfortable reminders' within the general command structure, ${ }^{17}$ it must be stressed that their largely pessimistic views did not stop them from preparing for the worst as well as they could. Befitting the prototypical soldier's duty not to give in easily, most of them remarked that trying to prepare was neither meaningless nor did it make a military conflict more likely, as was the opinion of various peace movements. On the contrary, a reasonable level of preparation, it was argued, could very well be for naught, but might still lead to some good. In one of his books on the subject, the Bundeswehr's foremost radiologist Otfried Messerschmidt put it this way:

Some might pose the question whether, in such a situation, anything should be done at all. Are not recommendations, as in this book for treating wounds, burns and radiation injuries under conditions of a massive holocaust, a pretense that a nuclear war can even be survived? Is it not naive to offer advice for a catastrophe that can be absolutely hopeless? If an impression of hopelessness results from reading this book, it is absolutely not the intention of the author. On the contrary, the information in this book is presented to spark initiative and imagination in a nuclear catastrophe in the firm belief that it will save human life. The will to help is not enough unless one knows what to do. [...] To be sure, nuclear war would be the most devastating event that could happen to mankind today. Should this catastrophe occur, against the will of all reasonable men, a medical service organization must stand ready to save as many lives as possible. (Messerschmidt 1979: xiv-iv)

The utilitarian notion to do whatever possible for as many as possible (cf. ZDv 49/50: 161) was a dominant motif of the early efforts of military physicians in these matters. Derived from traditional professional ethics, it served as a utopian counterpoint to the dystopian imaginary of nuclear annihilation. The medical method for achieving the necessary agency during the imagined disastrous was, however, highly controversial: triage - the process of selecting whom to treat and whom not to, in the case of injuries either too minor or too grievous, at times when there are too few physicians to be able to care for an overwhelming number of patients (cf. Koslowski 1969: 47). This last-resort measure of emergency medicine, barely contested in most countries, reminded many 
Germans of the murderous selections which had occurred in Auschwitz and other National Socialist concentration camps. Nevertheless, for the military physicians dealing with civil defence issues, developing more effective methods of triage was considered vital. For them, triage was not linked to Nazism, but to their own professional past of practising surgery on the battlefields of the Second World War. ${ }^{18}$ Most of the early medical officers of the Bundeswehr had been part of the Webrmacht as well and ultimately regarded medical civil defence as a means of keeping something 'honourable', which had helped to save the life of many a soldier, from a tainted past.

In comparison with the Federal Republic's general military force, its dedicated medical service had been founded belatedly (1956 as opposed to 1955) and was deemed inferior to the army, air force and navy untildepending on one's viewpoint-1957 or even 1965. ${ }^{19}$ The prestige of military physicians was often considered lacking, ${ }^{20}$ and early medical officers sought out civil defence as a possibility of re-entering a working relationship with their civilian colleagues in a field which would affect all physicians in times of national crisis. ${ }^{21}$ Apart from military officers such as Gustav Sondermann or Kurt Groeschel, civilian officials, too, supported such cooperative efforts, as they feared the military might otherwise veer away from the civilian sphere as it had done in the leadup to and during the World Wars. Hans Neuffer, inaugural president of the newly founded Bundesärztekammer (German Medical Association), ${ }^{22}$ expressly supported the military physicians' efforts to counteract 'disaster situations' while insisting that they had to remain medical doctors first and officers second. ${ }^{23}$

It is difficult to assess whether such endeavours were motivated primarily by an effort to keep the young democracy and its fragile institutions on track or simply to heighten their own professional power-or both. While still enjoying substantial societal prestige and solid incomes, it took German physicians some time to distance themselves from a past in which they had played a problematic part at best. They had been heavily involved in all top-level National Socialist organisations. As many as $45 \%$ had been members of the NSDAP, $26 \%$ of the SA and $9 \%$ of the SS (cf. Freimüller 2001: 14), and increasing revelations of nefarious medical crimes motivated many to keep their ranks closed. It was believed that strong ties between the diverse fields of the profession would quell internal turmoil which, in the end, was not in anyone's interest, as it 
endangered the strength of the profession as a whole. From this perspective, disaster medicine, which medical civil defence became increasingly known as from the late 1960s onwards, was a viable subject for bringing physicians from various fields together to work on. While it was originally derived from war surgery, it could - in the eyes of its proponents-only serve its purpose if every physician knew how to adhere to its central premise: the 'radical compulsion to think differently' (Rebentisch 1979: 99), in other words to turn from individual medicine to mass medicine in times of large-scale emergencies, using triage to save as many lives as possible. It may seem ironic then, that for all these efforts the actual implementation of disaster medicine was most effectively fuelled not by the military, nor even by the threat of war, but by something which had thus far eluded everyone's imagination: nuclear power plants.

The first major working group of the Bundesärztekammer associated with the potential dangers of the encroaching civilian use of nuclear power was founded in 1973 by renowned radiologist Emil Graul. Its results were published in 1975 (Scientific Council of the Bundesärztekammer 1975) and met with large-scale resentment at the 1976 German Medical Assembly (Deutscher Ärztetag) - the so-called 'parliament of the medical profession' in West Germany. Not only were its findings deemed too positive overall, with little regard paid to the problems stemming from radioactive waste materials, but the fact that several members of Graul's group had been on nuclear industry payrolls was also criticised. ${ }^{24}$ Because high-ranking officials of the Bundesärztekammer were wary of political controversies within its ranks, a potential follow-up panel was to focus exclusively on the medical implications of nuclear power plants while avoiding easily 'politicised' issues such as radioactive waste. Furthermore, it had to refrain from inviting physicians with close ties to the industry. ${ }^{25}$ Apart from the nuclear industry, however, most physicians specialising in radiation sickness belonged to the military. Thus, this latter demand opened up the chance to realise the hopes for cooperation expressed early on by military medical officers. More than twenty years after it had been originally proposed, an eclectic group of well-respected civilian and military physicians began creating a national scheme for disaster medicine, among them: the first German anaesthesiologist, Rudolf Frey; the civilian burn injury specialist Leo Koslowski; the already mentioned military physician Otfried Messerschmidt, renowned for having trained with radiology luminary Hanns Langendorff; and Ernst Rebentisch, retired chief 
inspector of the Bundeswehr's medical service, the highest rank any medical officer could achieve.

Two working groups followed Emil Graul's original one, the first led by radiologist Hanno Poppe (cf. Scientific Council of the Bundesärztekammer 1981) and the second by military surgeon Rebentisch. Although a detailed reconstruction of the actual meetings cannot be provided here, the mere titles of the respective groups are telling. Graul's panel had been called 'Risks of Nuclear Power Plants'-indeed a title which did not necessarily restrict its focus to medical issues. In contrast to that, Poppe's working group 'Emergency Response of Physicians in Nuclear Power Disasters' concentrated strictly on the medical aspects of such disasters and imagined a single scenario: a reactor meltdown, deemed highly unlikely but theoretically possible. The final group, led by Ernst Rebentisch, began its work in 1981, resulted in two major publications in 1986 and $1988^{26}$ and was simply called 'Deployment of Physicians during Disaster Events', its title being all but stripped of political overtones while generalising the nature of the imagined disastrous to effectively include almost anything.

Rebentisch himself was very much aware of the implications. For him, the all-hazards approach which was dominating civil defence officials' thinking at the time seemed all but mandatory. Indeed, he and his peers rejected the possibility that a physician could seriously prepare for the aftermath of a reactor meltdown without also preparing for at least a limited nuclear attack. Whereas the scale was certainly envisioned to be different, as was the asset of an intact medical service during times of peace, the required professional preparation, learning about triage, treating burns, radiation sickness and so on, seemed to remain completely unchanged. Therefore, Rebentisch could and deliberately did refer to disaster situations to avoid mentioning the highly unpopular term 'war' while still aiming for some basic wartime preparation of physicians. ${ }^{27}$ However, having served in a variety of alternative scenarios himself-he had led the medical operation during the Palestinian terrorist attack on the Israeli team of the 1972 Summer Olympics in Munich, for example ${ }^{28}$ — he did not regard talking of disasters solely as a rhetorical cloak, either. Rather, he tried to push the less controversial topic of disaster relief instead of civil defence because, as already stated, the professional consequences of improving both were identical in his opinion. 
The debates surrounding a proposed Gesundheitssicherstellungsgesetz (GesSG) may serve as an example for this approach. The name of this bill was-whether chosen deliberately or not-highly complex, potentially misleading and difficult to translate. Sicherstellungsgesetze- laws 'to safeguard something'-are meant to guarantee the function of specific key services in times of national crises, in this case focusing on health. The GesSG belonged to a set of emergency laws (Notstandsgesetze) which were publicly embattled during the late 1960s. As an approved expert, Ernst Rebentisch was asked by the Bundesärztekammer to comment on the individual paragraphs of the draft. Rebentisch agreed with some of the key measures proposed therein, such as the registration of all medical workers (including those not currently employed) and the right to assess medical facilities for their potential use in mass casualty situations. Nevertheless, he and his peers remained highly critical of the bill. The knowledge of physicians in all matters of preparation concerning both disaster and war-which in Rebentisch's view had to be included from the planning stage onwards - tended to be ignored rather than sufficiently heeded. Throughout all his annotations, however, one wish was clearly paramount: to erase the term Verteidigungsfall ('in the case of national defence', a common euphemism for war) as thoroughly as possible and substitute it with 'disaster'. ${ }^{29}$ Again, while Rebentisch was aware of the diplomatic advantage of this proposed change in terminology, the reasoning went beyond rhetoric. On multiple occasions, he insisted that the existing framework of medical disaster relief was even worse off than respective war preparations, which could at least rely on the Bundeswehr, and although the federal GesSG bill had no immediate jurisdiction on disaster relief issues as such, Rebentisch hoped that it would be interpreted by the individual states as an urgent call for action to improve their own legal situation. ${ }^{30}$ Moreover, because of the dual-use nature of civil defence as delineated by the KatSG-68, any measures the federal state provided to improve it could potentially be used by the individual states for disaster relief as well.

Naturally, this all-hazards approach was, and still is, controversial in and of itself. As was hinted at earlier, it is a generalisation, if not a misconception, that civil defence measures may most easily be realised in times of crises. For the West German case at least, the very opposite seems to have been true. During times of détente, laws could be passed, structures established which would have met with widespread public and parliamentary resistance during the high points of the East-West conflict. 
The years surrounding the Cuban Missile Crisis and the construction of the Berlin Wall in the early 1960s, as well as the NATO DoubleTrack Decision of the early 1980s led to multiple failed civil defence endeavours, since politicians feared public backlash. The outspoken peace movements of the early 1980s, for instance, were highly active in West Germany. Most dangerous to Rebentisch and other chamber experts were dissenting, well-respected physicians such as Ulrich Gottstein or HorstEberhard Richter who labelled specific preparations-especially training in triage - as a professional brand of warmongering in line with National Socialist' genocidal politics. Organised as the West German section of the International Physicians for the Prevention of Nuclear War (IPPNW) and praised by being awarded the Nobel Peace Prize in 1984, they achieved a sizeable amount of popularity and influence during the first half of the 1980s. They never represented a majority of physicians in West Germany, though, and ultimately failed to prevent a majority of the disaster medicine workgroup's goals (for a case study of the Swiss IPPNW, see chapter by Marti in this volume). It was not only the return of a politics of détente during the mid-1980s, however, which led to their defeat. Parallel to the widely discussed publication of Ulrich Beck's seminal work Risikogesellschaft (Risk Society, cf. Beck 1986), the reactor meltdown of the Chernobyl power plant on 26 April 1986 offered disaster medicine an opportunity to shine. Since scenarios above mere accidents, but below all-out nuclear war had always been those for which civil defence preparation might offer some kind of solace, physicians such as Rebentisch could now point to Chernobyl to support their call for additional preparedness while the West German section of the IPPNW gradually started to criticise nuclear power just as much as nuclear weapons. ${ }^{31}$

In 1989, the KatSG-68 was somewhat revised, and though its changes-brought about by the, again, awkwardly named Katastrophenschutzergänzungsgesetz (Amendment to the Disaster Relief Act)—could hardly be considered revolutionary, this revision realised some of the most important points professionals such as Ernst Rebentisch had been demanding for many years. Physicians were now integrated into crisis units from the planning stages onwards, and senior emergency physicians were given full authority over medical issues. ${ }^{32}$ Over time, teaching triage and general disaster medicine became less controversial-though never unanimously supported-proving worthwhile in many a humanitarian relief operation, most of them abroad, during floods, earthquakes and-indeed-military conflicts. ${ }^{33}$ However, contrary to the ambitions of 
Rebentisch and his peers at the time, disaster medicine never emerged as a separate field of medical studies but became a part of emergency medicine, from which it does not fundamentally differ at the present time, apart from in its scope and severity.

\section{CONCLUSION}

For the year 1988, Martin Diebel states that the combined financial efforts at federal and state level for their dual-use 'expanded disaster relief' amounted to 3.7 billion Deutsche Mark-a sizeable sum indicating that civil defence had changed rather than failed in West Germany, as had the underlying sociotechnical imaginary of its proponents.

In the most prominent front state of the Cold War, split apart between opposing military alliances and hosting thousands of nuclear warheads, concepts of total defence had a hard time being accepted. Even the most expansive measures could not offer any guarantee, and ultimately, officials had to admit that everything hinged on the hope that the enemy simply might not want to eradicate West Germany. To be sure, many people chose to remain ignorant of the possible dangers out of comfort or denial, but some also remembered vividly what kind of fury could be unleashed by conventional bombardment alone. And while the equations between National Socialism and medical prioritisation processes regularly put forth by members of the West German IPPNW may seem absurd from today's perspective, if not downplaying the actual holocaust, they attest to the paramount role national history played in rendering expansive civil defence measures precarious to even utter. Additionally, every year that nuclear war did not happen raised the perceived necessity to focus on scenarios that did. The North Sea flood of 1962 was not hypothetical but a reality, and it did not stand alone. The Ramstein air show disaster of 1988, for instance, resulted in dozens of casualties and led to massive criticism of the poor state of disaster medicine and general emergency preparedness. Chernobyl motivated even IPPNW activists to publish a pamphlet reminiscent of the 1960s' civil defence brochures, ${ }^{34}$ lending credence to the saying that during an actual crisis, even the worst critics of civil defence will try to seek shelter (Schneider 1962: 78).

Ultimately, civil defence in West Germany did not so much profit from the crises situations of the Cold War as it profited from peace. The respective officials and institutions who had initially talked of 'disasters' to avoid mentioning their real objective gradually started to believe 
their own rhetoric from the mid-1960s onwards. In a society growing ever more complex, the imagined disastrous expanded, including more and more scenarios of varying severity, all of them unlikely, but none impossible. Just as the discussions surrounding disaster medicine became more pragmatic and less steeped in moralising subtext, the underlying sociotechnical imaginary of general civil defence was gradually brought in line with attainable countermeasures that focused on volunteer relief work and medical training rather than digging holes in the ground.

\section{Notes}

1. This article focuses on German literature and sources. Although 'catastrophe' might seem to be the more literal translataion of the German term Katastrophe, its actual use is much more akin to 'disaster', as can be showcased by numerous word pairings such as Katastrophenschutz ('disaster relief'), Katastrophenfilm ('disaster movie') and so on. Thus, 'disaster' was chosen as the most appropriate translation.

2. Both the writings of Agamben (cf. 2001: 8-14) and studies belonging to the theory of 'securitisation' (cf. Buzan et al. 1998 as an introduction) tend to support the notion that very few disastrous events require additional executive powers, but they are often abused by governments to this effect, e.g. by proclaiming states of emergency to bypass parliamentary control.

3. In matters of civil defence, the German Democratic Republic had more in common with the Soviet Union than with West Germany (cf. Müller 2009).

4. While the nuclear attacks on Hiroshima and Nagasaki provided a grim database from which to extrapolate the effects of larger scale conflicts, such deductions remained theoretical. Moreover, relevant research was not yet widely available in Germany during the 1950s.

5. See also the chapters by Bjørnsson, Hogg and Farbøl in this volume.

6. The BLSV, originally called Luftschutzverein, was founded as early as 1946, while the THW followed in 1950. They were recognised as federal institutions in 1951 (BLSV) and 1953 (THW).

7. For more detailed information on the genesis of the central institutions of German civil defence, cf. Steneck (2005) and, for the BzB, Geier (2003). 
8. Many authors have underlined Germany's reliance on private associations (Verbände) in order to organise its politics, economy and culture (cf. Sebaldt and Straßner 2004). It may not even be widely known to the public, but although both disaster relief and general medical services appear to function as professional entities, they are, in fact, heavily reliant on the volunteer workers of various private associations (e.g. the German Red Cross, the Arbeiter-SamariterBund, the Johanniter-Unfall-Hilfe, the Malteser-Hilfsdienst, but also the THW and countless local fire departments). The consent of these associations proved to be a necessity for any civil defence reform. Their voluntary nature was certainly instrumental in achieving that status: politicians hardly dared to act against their will because they feared losing the only workforce they had-a workforce which, being unpaid, could easily quit at any moment.

9. Technisches Hilfswerk (ed.), Flüchtlingshilfe: Herausfordernde Aufgabe für das THW. Mission report, 18 September 2015, https://www.thw.de/SharedDocs/Meldungen/DE/Einsaetze/ national/2015/09/meldung_006_ fluechtlingshilfe.html?param $=1,530,411,514,789 \&$ \&aram 3 = jsoff; Corona-Einsatz: THWKräfte unterstützen Gesundheitsämter. Press statement, 11 November 2020, https://www.thw.de/SharedDocs/Meldungen/ DE/Einsaetze/national/2020/corona/meldung_060_corona_ einsatz_ll11.html;jsessionid=4FF40CE73B12796A33349214 5257BDEC.1_cid379?nn=924754 [both accessed 13 November 2020].

10. Cf. recent data taken from online press releases based on the 2019 yearbooks of both organisations: https://www.thw.de/ SharedDocs/Meldungen/DE/Pressemitteilungen/national/ 2020/05/pressemitteilung_002_thw_jahresbericht_2019.html; https://www.drk.de/presse/pressemitteilungen/meldung/jah resbericht-2019-zahl-der-ehrenamtlichen-helfer-beim-drk-ste igt-weiter/\#: :text=Das\%20Deutsche\%20Rote\%20Kreuz\%20\% 28DRK\%29\%20verzeichnet\%20erneut\%20einen,8.500\%20auf\%20i nsgesamt $\% 20,443.300 \% 20$ Helferinnen $\% 20$ und $\% 20$ Helfer $\% 20$ gest iegen [accessed 12 November 2020].

11. For more detailed sociological remarks concerning physicians and other 'professionals', see the writings of Freidson (e.g. 1986). 
12. IV $\mathrm{H}$ an Abteilungsleiter IV vom 13.5.1957, Betr.: Organisation des Führungsstabes des Gesundheits- und Sanitätswesens der Bundeswehr. BArch-MA, BW 24/20790.

13. The affair is usually considered a cornerstone in establishing the early Federal Republic's freedom of the press. It involved the political magazine Der Spiegel being accused of treason because it had published an article containing details about the German military's poor performance during Fallex 62 (cf. 'Bedingt abwehrbereit', Der Spiegel 41/1962, http://magazin.spiegel.de/EpubDelivery/ spiegel/pdf/25673830).

14. Erfahrungsbericht über die NATO-Herbstübung 'FALLEX 62' vom 6.-27.9.1962; Anlage zu BMI VII B 5 (Gekürzte Fassung), p. 10. DRK, 4274.

15. Üb-Kriegstagebuch Nr. 1-KNDS-SAN FÜ. BArch-MA, BW 24/173.

16. WITEX SILVER/InSan II 1, Lagebeitrag Sanitäts- und Gesundheitswesen vom 13.3.1975. BArch-Ma, BW 24/5432.

17. Gustav Sondermann, 'Über das Leitbild des Arztsoldaten', in Gespräch über militärärztliche Fragen vom 22. bis 24. Oktober [1956] an der Evangelischen Akademie Loccum, p. 28. BArch-MA, BW $51 / 1$.

18. C.f. Schreiben von Hermann Kater an Karsten Vilmar vom 28.8.1983. BArch, B 417/146.

19. The medical service became an independent part of the German military in 1957, but its commander (Inspekteur) was deemed inferior compared to the others until 1965.

20. c.f. Georg Meyer, Aktennotiz vom 7.3.1979. BArch-MA, BW $24 / 7796$.

21. Kurt Groeschel, Gedanken zur Koordination von aktiven San. Offizieren und Zivilärzteschaft, 20 June 1956. BArch, B 389/112.

22. The official translation-German Medical Association-is somewhat misleading, as the Bundesürztekammer is not a typical association based on voluntary membership, but a 'chamber' (Kammer). All German physicians are organised within a so-called chamber system granting them professional autonomy as well as some federally guaranteed privileges. Membership in one's respective state-level chamber (Landesärztekammer) is mandatory for every practising physician. The delegates of these state-level chambers constitute the Bundesärztekammer, which serves as both a lobby 
organisation and a professional think-tank usually focusing on issues which demand federal standards, such as medical ethics.

23. Hans Neuffer, 'Die deutsche Ärzteschaft zum Aufbau des Sanitätswesens der Bundeswehr', in Gespräch über militärärztliche Fragen vom 22. bis 24. Oktober [1956] an der Evangelischen Akademie Loccum, p. 18-23. BArch-MA, BW 51/1.

24. Cf. Das Risiko der Kernkraftwerke, in Deutsches Ärzteblatt 1/1973, p. 21-23.

25. Hanno Poppe, 18. Plenarsitzung des Wissenschaftlichen Beirats der BÄK (5.5.1979, Köln, Bundesärztekammer), TOP 3 C-Arbeitskreis ‘Ärztliche Hilfe bei Katastrophen', p. 1. BArch, B 417/864.

26. The first publications were the Denkschrift Katastrophenmedizin (Position Paper on Disaster Medicine, Bundesärztekammer 1986), a short pamphlet primarily designed to put pressure on the legislative process, and the second opus magnum by Rebentisch, the Handbuch der medizinischen Katastrophenhilfe (Handbook of Medical Disaster Relief), containing detailed instructions for a multitude of medical fields in varying scenarios (Rebentisch 1988).

27. Letter from Ernst Rebentisch to Heinz-Peter Brauer vom 8.2.1982. BArch, B 417/154.

28. Cf. Laudatio zur Verleihung der Paracelsus-Medaille an Prof. Dr. med. Ernst Rebentisch, https://www.bundesaerztekammer.de/fil eadmin/user_upload/downloads/Lau-rebentisch.pdf [accessed 13 November 2020].

29. Letter from Ernst Rebentisch to Heinz-Peter Brauer vom 13.10.1980. BArch, B 417/160.

30. Cf. Ernst Rebentisch, Beantwortung des Fragenkatalogs zur Anhörung am 6.10.1989. BArch, B 417/2924.

31. Since this paper focuses on civil defence rather than its critics, it cannot offer a detailed analysis of the IPPNW. For a study on the German section cf. Kemper (2016). As with general peace movements, opinions of the IPPNW both then and now were and are mixed. On the one hand, they were credited with softening the dividing line between friend and foe during the Cold War and for offering educational information on the 'untreatable' horror of nuclear war. On the other hand, they were criticised for one-sidedly condemning the defence preparations of liberal democracies while turning a blind eye to the totalitarian nature of the USSR, which cruelly persecuted dissenting activists at home. 
32. Cf. Entwurf eines Gesetzes zur Ergänzung des Katstrophenschutzgesetzes und anderer Vorschriften (Katastrophenschutzergänzungsgesetz-KatSErgG), Stand: 8.9.1988. FZH, 16$3 \mathrm{~A} / 2.3 .-7$.

33. A former student of Leo Koslowski, surgeon Bernd Domres alone led approximately 50 missions abroad (e.g. in Cambodia, Haiti, Nigeria and Pakistan) and co-founded the German Institute for Disaster Medicine, cf. https://www.stiftung-difkm.de/team/kur zvitae/ [accessed 13 November 2020].

34. Lutz Castell and Katharina Strecker (Institut für Umweltuntersuchungen Starnberg e.V.), Maßnahmen beim nächsten SuperGAU, 10 April 1987. FZH, 16-3 A/17.3-5.

\section{REFERENCES \\ UNPUBLISHED SOURCES}

Federal Archives of Germany, in Koblenz (BArch).

- Holdings of the Bundesärztekammer (German Medical Association, B 417).

- Holdings of the Hartmannbund (Association of German Physicians, B 389). Federal Archives of Germany-Military Archive, in Freiburg (BArch-MA).

- Holdings of the Inspektion des Sanitätswesens der Bundeswehr (Inspectorate of the Military Medical and Health Services, BW-24).

- Holdings of the Deutsche Gesellschaft für Wehrmedizin und Wehrpharmazie e.V. (German Society for Military Medicine and Military Pharmacy, BW 51).

Archive of the Research Centre for Contemporary History in Hamburg (Forschungsstelle für Zeitgeschichte in Hamburg, FZH).

- Holdings of the Deutsche Sektion der IPPNW (West German section of the International Physicians for the Prevention of Nuclear War, 16-3 A).

Archives of the General Secretariat of the German Red Cross, in Berlin (DRK).

\section{LiTERATURES}

Abbot, Andrew. 1988. The system of professions: An essay on the division of expert labor. Chicago: Chicago University Press.

Agamben, Georgio. 2001. Ausnabmezustand (homo sacer 2.1). Translated into German by Ulrich Müller-Schott. Frankfurt/M.: Suhrkamp.

Bayer, Alfred. 1962. Gedanken über die Sanitätstaktik in einem Verteidigungsfall. Wehrmedizinische Mitteilungen: 161-164 (part I), 178-180 (part II), 196198 (part III). 
Beck, Ulrich. 1986. Risikogesellschaft. Frankfurt/M.: Suhrkamp.

Berger Ziauddin, Silvia. 2017. Superpower Underground: Switzerland's rise to global bunker expertise in the Atomic Age. Technology and Culture 58: 921954.

Biess, Frank. 2009. Jeder hat eine Chance: Die Zivilschutzkampagnen der 1960er Jahre und die Angstgeschichte der Bundesrepublik. In Angst im Kalten Krieg, eds Bernd Greiner, Christian Th. Müller and Dirk Walter, 61-93. Hamburg: Hamburger Edition.

Biess, Frank. 2019. Republik der Angst: Eine andere Geschichte der Bundesrepublik. Hamburg: Rowohlt (Published in English in 2020 as: German Angst: Fear and democracy in the Federal Republic of Germany. Oxford: Oxford University Press).

Bundesärztekammer, ed. 1986. Denkschrift Katastrophenmedizin. Deutsches Ärzteblatt 16: 1097-1111.

Bundesamt für zivilen Bevölkerungsschutz (BzB), ed. 1961. Jeder hat eine Chance. Bad Godesberg: BzB.

Bundesamt für zivilen Bevölkerungsschutz (BzB), ed. 1964. Zivilschutzfibel: Informationen, Hinweise, Ratschläge. Bad Godesberg: BzB.

Buzan, Barry, Ole Wrver and Jaap de Wilde. 1998. Security: A new framework for analysis. Boulder: Lynne Rienner Publishers.

Conze, Eckart. 2009. Die Suche nach Sicherheit: Eine Geschichte der Bundesrepublik Deutschland von 1949 bis in die Gegenwart. München: Siedler.

Davis, Tracy. 2007. Stages of emergency: Cold War nuclear civil defence. Durham: Duke University Press.

Diebel, Martin. 2017. Atomkrieg und andere Katastrophen: Zivil- und Katastrophenschutz in der Bundesrepublik und Großbritannien nach 1945. Paderborn: Ferdinand Schöningh.

Freidson, Eliot. 1986. Professional powers: A study of the institutionalization of formal knowledge. Chicago: Chicago University Press.

Freimüller, Tobias. 2001. Mediziner: Operation Volkskörper. In Karrieren im Zwielicht: Hitlers Eliten nach 1945, ed. N. Frei, 13-69. Frankfurt/M.: Campus.

Garrison, Dee. 2006. Bracing for Armageddon: Why civil defence never worked. Oxford: Oxford University Press.

Geier, Wolfram. 2003. Zwischen Kriegsszenarien und friedenszeitlicher Katastrophenabwehr: Zur Entwicklung der zivilen Verteidigung in der Bundesrepublik Deutschland unter besonderer Berücksichtigung des Zivilschutzes und seiner Reformen vor und nach Beendigung des Kalten Krieges. Doctoral dissertation, Marburg.

Imhof, Kurt. 2004. Katastrophenkommunikation in der Moderne. In Katastrophen und ihre Bewältigung: Perspektiven und Positionen, eds Peter Rusterholz and Rupert Moser, 145-163. Bern: Haupt. 
Kemper, Claudia. 2016. Medizin gegen den Kalten Krieg: Ärzte in der antiatomaren Friedensbewegung der 1980er Jabre. Göttingen: Wallstein Verlag.

Kessel, Nils. 2008. Geschichte des Rettungsdienstes 1945-1990: Vom 'Volk von Lebensrettern' zum Berufsbild 'Rettungsassistent/in'. Frankfurt/M.: Peter Lang.

Klinke, Ian. 2018. Cryptic concrete: A subterranean journey into Cold War Germany. Hoboken: Wiley.

Koslowski, Leo. 1969. Die Sichtung (Triage) der Verletzten bei Massenkatastrophen. Katastrophenmedizin (supplement to Webrmedizin), $7^{\text {th }}$ annual volume: 46-49.

McEnaney, Laura. 2000. Civil defense begins at home: Militarization meets everyday life in the fifties. Princeton: Princeton University Press.

Messerschmidt, Otfried. 1979. Medical procedures in a nuclear disaster: Pathogenesis and therapy for nuclear-weapons injuries. München: Thiemig.

Moeller, Robert. 2001. Remembering the war in a nation of victims. In The miracle years: A cultural history of West Germany 1949-1968, ed. Hannah Schissler, 83-109. Princeton: Princeton University Press.

Molitor, Jochen. 2011. Mit der Bombe überleben: Die Zivilschutzliteratur der Bundesrepublik 1969-1964. Marburg: Tectum.

Molitor, Jochen. 2014. Lehren für den Verteidigungsfall: Die Sturmflutkatastrophe von 1962 und der bundesdeutsche Zivilschutz. In Die Hamburger Sturmflut von 1962: Risikobewusstsein und Katastrophenschutz aus zeit-, technik- und umweltgeschichtlicher Perspektive, eds M. Heßler and C. Kehrt, 195-221. Göttingen: Vandenhoeck \& Ruprecht.

Müller, Christian Th. 2009. Im Banne der Bombe: Überlegungen zu Luftschutz und Zivilverteidigung in der DDR. In Angst im Kalten Krieg, eds Bernd Greiner, Christian Th. Müller and Dirk Walter, 94-122. Hamburg: Hamburger Edition.

Münkler, Herfried. 2013. Revolution, Krieg \& Katastrophe: Ein Diskurs über Domestizierung und Enthegung. In Aufbruch ins Unversicherbare: Zum Katastrophendiskurs der Gegenwart, eds Leon Hempel, Marie Bartels and Thomas Markwart, 95-139. Bielefeld: Transcript.

Rebentisch, Ernst. 1979. Katastrophenmedizin. Wehrmedizinische Monatsschrift 4: 97-100.

Rebentisch, Ernst. 1988. Handbuch der medizinischen Katastrophenhilfe. München-Gräfelfing: Werk-Verlag Banaschewski.

Rose, Kenneth. 2001. One nation underground: The fallout shelter in American culture. New York: New York University Press.

Sautier, Hermann. 1961. Der Weg des BLSV. Zivilschutz 25: 44-48.

Schmidt, Helmut. 1962. Verteidigung oder Vergeltung: Ein deutscher Beitrag zum strategischen Problem der NATO. Stuttgart-Degerloch: Seewald.

Schneider, Wolf. 1962. Hat jeder eine Chance? Neuenbürg: Osang. 
Scientific Council of the Bundesärztekammer, ed. 1975. Stellungnahme zum Thema 'Gefährdung durch Kernkraftwerke'. Deutsches Ärzteblatt 41: 28212824.

Scientific Council of the Bundesärztekammer, ed. 1981. Zur Frage der ärztlichen Versorgung der Bevölkerung bei Kernkraftwerksunfällen. Köln: Deutscher Ärzte-Verlag.

Sebaldt, Martin, and Alexander Straßner. 2004. Verbände in der Bundesrepublik Deutschland: Eine Einführung. Wiesbaden: Verlag für Sozialwissenschaften.

Steneck, Nicholas. 2005. Everybody has a chance: Civil defence and the creation of Cold War West German identity, 1950-1968. Doctoral dissertation. Columbus, Ohio.

Steneck, Nicholas. 2008. Eine verschüttete Nation? Zivilschutzbunker in der Bundesrepublik Deutschland 1950-1965. In Bunker: Kriegsort, Zuflucht, Erinnerungsraum, eds Inge Marszolek and Marc Buggeln, 75-88. Frankfurt/M.: Campus.

Wolfrum, Edgar. 2006. Die geglückte Demokratie: Geschichte der Bundesrepublik Deutschland von ibren Anfüngen bis zur Gegenwart. Stuttgart: Klett-Cotta.

ZDv 49/50: Die dringliche Kriegschirurgie. Übersetzung des NATO-Handbook Emergency War Surgery (1958). Bonn: Bundesministerium der Verteidigung. November 1961.

Open Access This chapter is licensed under the terms of the Creative Commons Attribution 4.0 International License (http://creativecommons.org/licenses/ by $/ 4.0 /$ ), which permits use, sharing, adaptation, distribution and reproduction in any medium or format, as long as you give appropriate credit to the original author(s) and the source, provide a link to the Creative Commons license and indicate if changes were made.

The images or other third party material in this chapter are included in the chapter's Creative Commons license, unless indicated otherwise in a credit line to the material. If material is not included in the chapter's Creative Commons license and your intended use is not permitted by statutory regulation or exceeds the permitted use, you will need to obtain permission directly from the copyright holder.

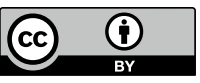

